\title{
Family reassignments and synonymy of some taxa of Neotropical Microlepidoptera
}

\section{Vitor O. Becker ${ }^{1}$}

\begin{abstract}
Fourteen genera and 23 species were misplaced and are assigned to their proper families, 11 genera and 10 species are synonymized, one genus and one species are ressurected from synonymy, and 18 species are new combinations.

KEY WORDS. Gelechioidea, Sesiidae, Yponomeutoidea, Neotropical, taxonomy
\end{abstract}

HEPPNER (1984: 57), listed 11 genera and 38 species of Heliodinidae for the Neotropical Region, leaving out 9 genera and 12 species formerly included in this family. As no references to the transfer of these taxa to other families were found, a list of the missing taxa was sent to him (BECKER 1984a). In a newsletter sent to the members of the project of the Atlas of Neotropical Lepidoptera (HEPPNER 1987: $3-7$ ) all these taxa were transferred to the Stathmopodini [=Stathmopodinae] (Oecophoridae).

During a visit to the Natural History Museum, London, in 1988, where most of the type material belonging to these taxa is deposited, it was found that none of them belongs to the Oecophoridae. The only exception is Machaerocrates tunicata Meyrick, whose type-specimen is deposited in the Naturhistorisches Museum, Vienna, that belongs to the Oeocophoridae. Being the author of all the gelechioid parts in the checklist (BECKER 1984a: 27-53) and having been acknowledged by HEPPNER (1987:3) as one of the contributors who supplied the information he used in the newsletter, it is obvious that subsequent authors would wrongly credit these changes to BECKER. In order to rectify this, a discussion on the correct placement of the taxa involved is presented here.

In the process of studying type-specimens, and visiting various museums in order to identify material in VOB, several other misplaced taxa have also been found. Their placement is also discussed here.

The taxa are arranged in alphabetical order by genus and by species under each genus. The information about the original placement and the new assignments is given in the discussion under each taxon. For the taxa previously illustrated references are given here, the others are illustrated whenever possible.

Abbreviations used in the text: (BMNH) The Natural History Museum, London, England; (CU) Cornell University, Ittaca, New York, USA; (FOC) Fundação Oswaldo Cruz, Rio de Janeiro, Brazil; (MNHN) Muséum National d'Histoire Naturelle, Paris, France; (IML) Instituto Miguel Lillo, Tucumán, Argentina; (NM) Naturhistorisches Museum, Vienna, Austria; (UMO) University Museum, Oxford, England; (UNLP) Universidade Nacional de La Plata, Argentina; (VOB) Collection Becker, Brasília, Brazil.

1) Research Associate, Departamento de Zoologia, Universidade de Brasilia, Caixa Postal 04525, 70919-970 Brasília, Distrito Federal, Brasil. 


\section{NOMENCLATURAL SUMMARY}

\section{Acrolepiidae}

Dasycarea Zeller (Ex Roeslerstammiidae)

viridisquamata Zeller

\section{Coleophoridae \\ Momphinae}

Echinophrictis Meyrick (Ex Oecophoridae)

triphracta Meyrick

Palaeomystella Fletcher (Ex Agonoxenidae)

chalcopeda (Meyrick)

Cosmopterigidae Antequerinae

Euclemensia Grote

Sisyrotarsa Meyrick, syn.n. (Ex Oecophoridae) caminopa (Meyrick), comb.n. (Ex Oecophoridae)

\section{Cosmopteriginae}

Cosmopterix Hübner, [1825]

Capanica Meyrick, syn.n. (Ex Oecophoridae)

astrophanes (Meyrick), comb.n. (Ex Oecophoridae)

lamprolitha (Meyrick), comb.n. (Ex Oecophoridae)

lamprodoxa (Meyrick), syn.n. (Ex Heliodinidae)

Cyphacma Meyrick (Ex Oecophoridae)

chalcozela Meyrick

Ecballogonia Walsingham

Harpograptis Meyrick, syn.n.

bimetallica Walsingham

eucharacta (Meyrick), comb.n.

Metallocrates Meyrick (Ex Blatobasidae)

Magorrhabda Meyrick, syn.n. (Ex Oecophoridae)

transformata Meyrick

elytrata (Meyrick), syn.n.

Triclonella Busck

albicellata (Meyrick), comb.n.

citrocarpa (Meyrick), comb.n.

mediocris (Walsingham), comb.n. (Ex Blastobasidae)

rhabdophora Forbes, syn.n.

breviramis (Meyrick), syn.n. 


\section{Chrysopeleiinae}

Stilbosis Clemens

sexgutella (Walker), comb.n. (Ex Heliodinidae)

chrysorrhabda Meyrick, syn.n.

\section{Elachistidae}

\section{Agonoxeninae}

Amblytenes Meyrick, stat. rev.

lunatica Meyrick, comb. rev.

revecta (Meyrick), comb.n.

Gnamptonoma Meyrick (Ex Oecophoridae)

leptura Meyrick

Pammeces Zeller

picticornis (Walsingham), comb.n. (Ex Coleophoridae)

Tocasta Busck (Ex Coleophoridae)

Diacholotis Meyrick, syn.n.

priscella Busck

iopyrrha (Meyrick), syn.n.

\section{Depressariinae}

Profilinota Clarke

Ilarches Meyrick (Ex Gelechiidae)

notaula (Meyrick), comb.n.

phillita Clarke, syn.n.

Gelechiidae

Gelechiinae

Nicanthes Meyrick

rhodoclea Meyrick

Percnarcha Meyrick (Ex Oecophoridae)

latipes (Walker), comb.n. (Ex Oecophoridae)

lilloi (Köhler), comb.n.

strategica Meyrick (Ex Oecophoridae)

trabeata Meyrick

Glyphidoceridae

Glyphidocera Walsingham

Ptilostonychia Walsingham, syn.n. (Ex Gelechiidae)

Stibarenches Meyrick, syn.n. (Ex Gelechiidae)

bifissa (Meyrick), comb.n.

plicata (Walsingham), comb.n. 


\section{Glyphipterigidae}

Cotaena Walker

Myrsila Boisduval, syn.n.

Encamina Meyrick, syn.n. (Ex Oecophoridae)

mediana Walker

auripennis (Boisduval), syn.n.

semifervens (Meyrick), syn.n. (Ex Oecophoridae)

phlegyropa (Meyrick), comb.n. (Ex Oecophoridae)

\section{Heliodinidae}

Amblyscopa Meyrick (Ex Oecophoridae)

isophaea Meyrick

\section{Oecophoridae \\ Stathmopodinae}

Tinaegeria Walker

Arauzona Walker, syn. rev.

Machaerocrates Meyrick, syn.n.

basalis (Walker), comb. rev.

clitarcha Meyrick

fasciata Walker

croconympha Meyrick, syn.n.

moorei (Busck), comb.n.

nephelozyga Meyrick

ochracea Walker

aeneiceps (Felder \& Rogenhofer)

pyromantis Meyrick

tunicata (Meyrick), comb.n.

\section{ALPHABETICAL CATALOGUE}

\section{Amblyscopa Meyrick, 1922}

Amblyscopa Meyrick, 1922a: 587. Type-species: A. isophaea Meyrick, 1922a: 588, by monotypy.

Described in the Heliodinidae, this monotypic genus was included in the Schreckensteiniadae [=Heliodinidae] by FLETCHER (1929: 11), and transferred to the Stathmopodini [=Stathmopodinae] (Oecophoridae) by HEPPNER (1987: 4). This is a monotypic genus and the type series of $A$. isophaea is in the BMNH. It is a true Heliodinidae.

Figs 1-8. Adults of Gelechioidea. (1) Gnamptonoma leptura, female; (2) Pammeces picticornis, male; (3) Amblytenes lunatica, male; (4) Triclonella mediocris, male; (5) Echinophrictis triphracta, male; (6) Nicanthes rhodoclea, female; (7) Cosmopterix lamprolitha, male; (8) C. astrophanes, female. 

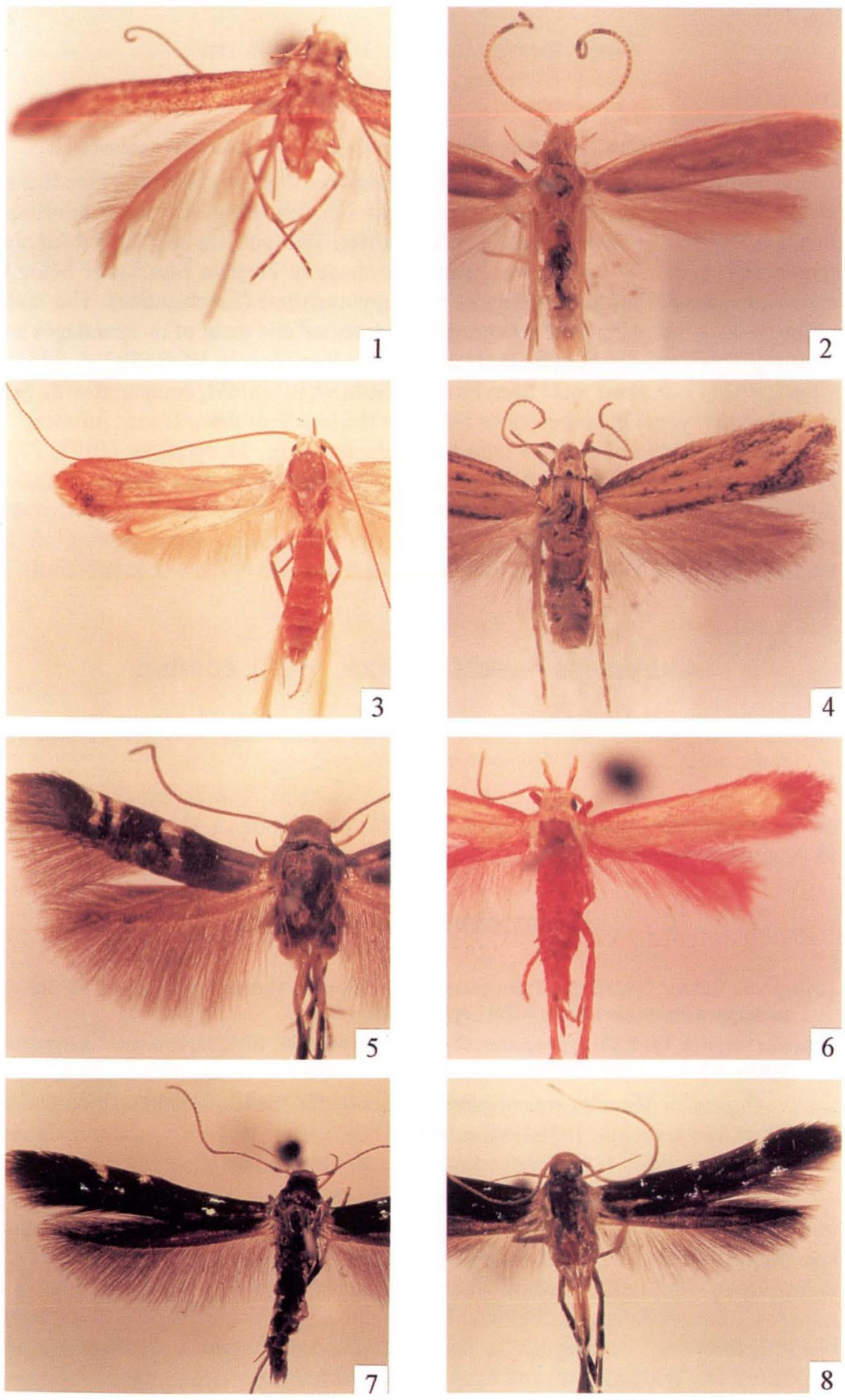

Revta bras. Zool. 16 (Supl. 2): 141 - 170, 1999 


\section{Amblytenes Meyrick, 1930, stat. rev.}

Figs $3,24,25$

Amblytenes Meyrick, 1930a: 229. Type-species: A. lunatica Meyrick, 1930a: 230, by monotypy

Originally described in the Cosmopterigidae, it was transferred to the Batrachedrinae (Coleophoridae) by BECKER (1984a: 42), following Meyrick's indication that it is related to Batrachedra Herrich-Schäffer. The type has been examined and its genitalia (Figs 24, 25) are very similar to those of Tocasta Busck (see below); and Nanodacna Clarke, currently in the Agonoxeninae (Elachistidae). The male holotype of $A$. lunatica (NM [examined]) is descaled and most of its apendages are missing. There is a series of males from BRAZIL: Rondônia in VOB $(80064,88840$, 94605, 96171), and one male from FRENCH GUIANA in USNM, compared with, and matching the type. One remarkable feature is the length of the antennae [missing in the type], considerably longer than the forewings (Fig. 3). HodGES (1997: 275) synonymized Amblytenes with Tocasta [see Tocasta below]. However, as there are differences, especially in the male genitalia [vinculum thin, round in Amblytenes whereas expanded as a broad saccus in Tocasta], it seems more appropriate to maintain both as distinct genera until a thorough revision of the whole subfamily is done.

\section{Amblytenes revecta (Meyrick, 1922), comb.n.}

Prochola revecta Meyrick, 1922a: 582. Lectotype male: GUIANA: Mallali, III.1913 (Parish) (BMNH), designated by Clarke, 1965: 526 [examined].

Hodges (1997: 275) transferred this species to Tocasta Busck. However, the male genitalia, ilustrated in CLARKE (1965: pl. 259, figs 1-1b) are more similar to those of A. lunatica (Figs 1,2), than to those of Tocasta.

\section{Cosmopterix Hübner, [1825]}

Cosmopterix Hübner, [1825]: 424. Types-pecies: Tinea zieglerella Hübner, [1810]: pl. 44, fig. 306, by subsequent designation by the ICZN (Opinion 866), 1969.

Capanica Meyrick, 1917: 63. Type-species: C. astrophanes Meyrick, 1917: 63, by original designation. syn.n.

Capanica Meyrick was originally described in the Heliodinidae, included in the Schreckensteiniadae [=Heliodinidae] by FLETCHER (1929: 39), and transferred to the Stathmopodini [=Stahmopodinae] (Oecophoridae) by HEPPNER (1987: 5).

The genitalia of the two species formerly belonging to Capanica clearly indicate that this is a synonym of Cosmopterix Hübner. In VOB there is one female specimen from Brazil (VOB 48309), compared with, and matching the type of $C$. astrophanes (Meyrick), comb.n. which is illustrated here (Fig. 8), and a series that match $C$. lamprolitha (see below). Both belong to a complex of species, with blackish forewings bearing silvery dots, that includes C. abnormalis Walsingham, C. irrubricata Walsingham, and C. nyctiphanes Meyrick. 

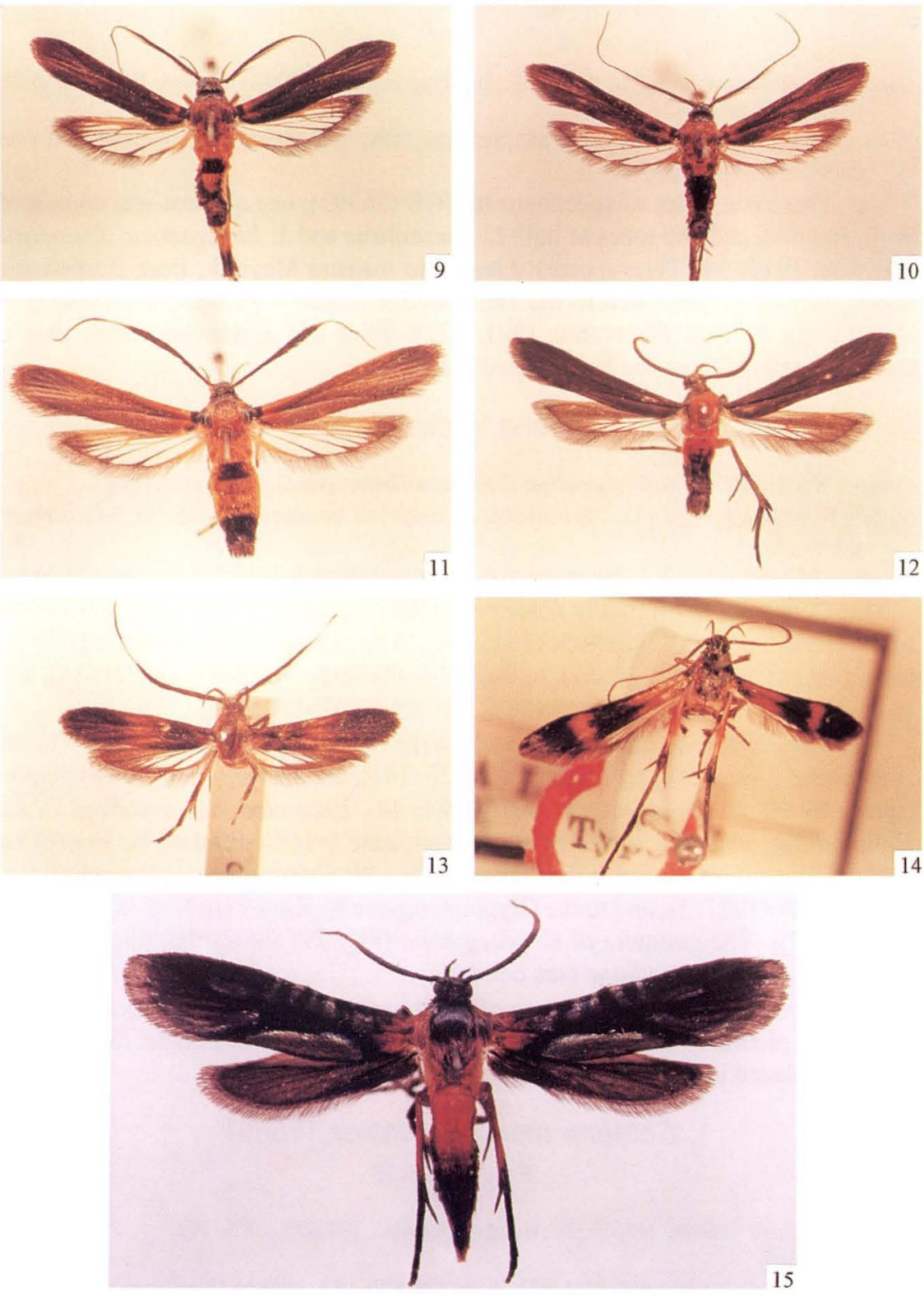

Figs 9-15. Adults of (9-14) Gelechioidea and (15) Glyphipterigidae. (9) Tinaegeria fasciata, male; (10) T. basalis, male; (11) T. fasciata, (female); (12) Percnarcha trabeata, male; (13) $T$. nephelozyga, male; (14) P. latipes, (holotype, female); (15) Cotaena mediana, male. 


\section{Cosmopterix lamprolitha (Meyrick, 1917), comb.n.}

Fig. 7

Capanica lamprolitha Meyrick, 1917: 63. Holotype male: GUIANA: Bartica, II.1913 (Parish) (BMNH)[examined].

Xestocasis lamprodoxa Meyrick, 1922a: 586. Syntypes: BRAZIL:[AM], Parintins, Manaus. X, XI.1919 (BMNH) [examined]. syn.n.

There is a series of specimens in VOB (56393), one of them was compared with, and matched, the types of both $C$. lamprolitha and X. lamprodoxa. Xestocasis Meyrick, 1914: 54 [Type-species: Limnoecia iostrota Meyrick, from Borneo and India], originally described in the Heliodinidae is also a gelechioid according to KIRKY (in NYE \& FLETCHER 1991: 322). With this synonymy Xestocasis is therefore deleted from the New World fauna.

\section{Cotaena Walker, [1865]}

Cotaena Walker, [1865]: 21. Type-species: C. mediana Walker, [1865]: 21, by monotypy.

Myrsila Boisduval, [1875]: 433. Type-species: M. auripennis Boisduval, [1875]: 433, by monotypy. syn.n.

Encamina Meyrick, 1915: 214. Type-species: E. phlegyropa Meyrick, 1915: 214, by monotypy. syn.n.

Cotaena was originally described in the Aegeriidae [=Sesiidae], transferred to the Heliodinidae by MEYRICK (1913: 18), to the Schreckensteiniadae [=Heliodinidae] by FLETCHER (1929: 57), to the Heliodinidae by NAUMANN (1971: 15), and to the Glyphipterigidae by HEPPNER \& DUCKWORTH (1981: 44).

Myrsila was originally described in the Sesiides [Sesiidae], included in the Aegeriadae [=Sesiidae] by FLETCHER (1929: 144), and tranferred to the Glyphipterigidae by HEPPNER \& DUCKWORTH (1981: 44). Encamina was described in the Heliodinidae, included in the Schreckensteniadae [=Heliodinidae] by FLETCHER (1929: 76), and transferred to the Stathmopodini [Stathmopodinae] (Oecophoridae) by HEPPNER (1987: 5), and to the Glyphipterigidae by KIRKY [in NYE \& FLETCHER (1991: 107)]. The genitalia of C. phlegyropa (Fig. 29) shows that this species is closely related to $C$. mediana (see below).

According to the characters of wing venation, shape of the genitalia and absence of pleural lobes on the eighth abdominal segment in the male, this genus is correctly placed in the Glyphipterigidae.

\section{Cotaena mediana Walker, [1865]}

Figs $15,26-28$

Cotaena mediana Walker, [1865]: 21. Holotype female : [BRAZIL: PA, Belém] "Pará" (UMO) [examined].

Myrsila auripennis Boisduval, [1875]: 433. Type: [BRAZIL: PA, Belém] "Pará" [presumably lost]. syn.n.

Encamina semifervens Meyrick, 1927: 379. Syntypes, 2 females: BRAZIL [no further data] (BMNH) [examined]. syn.n.

This is a colourful species (Fig. 15) widespread throughout the Amazon. There is a good series from the states of Maranhão, Pará and Rondônia in VOB. The 

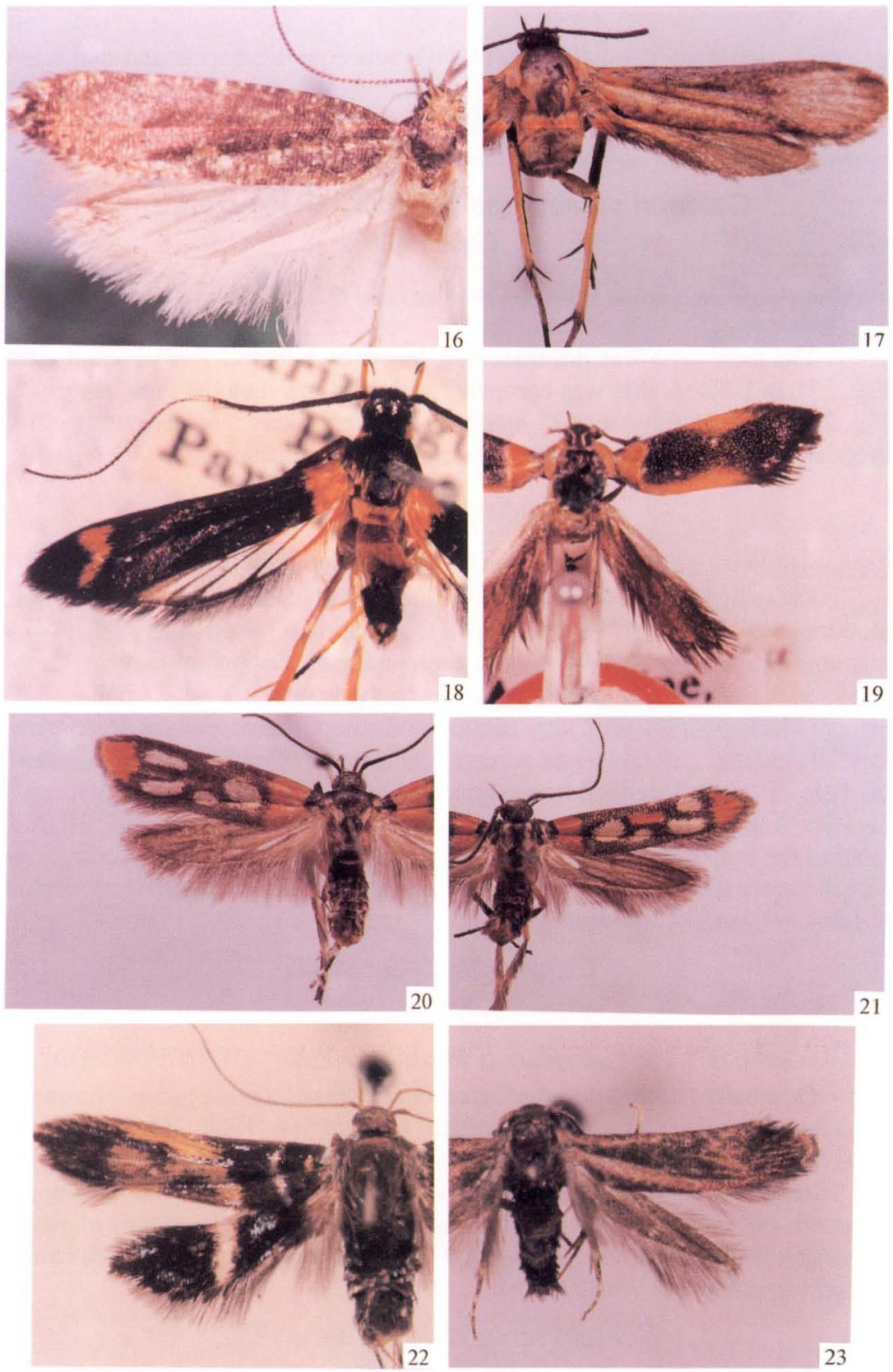

Figs 16-23. Adults of (16) Acrolepiidae, (17) Glyphipetrigidae, and (18-23) Gelechioidea. (16) Dasycarea viridisquamata, holotype, female; (17) Cotaena phlegyropa, female; (18) Tinaegeria pyromantis, male, holotype; (19) Euclemensia caminopa, female, holotype; (20) Triclonella albicellata, male; (21) T. citrocarpa, male; (22) Ecballogonia bimetallica, male; (23) Metallocrates transformata, male. 
specimen from Pará: Capitão Poço (53883) was compared with, and matched the types of $C$. mediana and $E$. semifervens respectively, and as does the series, matches the illustration of M. auripennis in ZUKOWSKY (1936: 1246, pl. 178i). The male and female genitalia (Figs 26-28) are illustrated here for the first time.

\section{Cotaena phlegyropa (Meyrick, 1915), comb.n.}

Figs 17, 29

Encamina phlegyropa Meyrick, 1915: 214. Holotype male: GUIANA: Bartica, II (Parish) (BMNH). [examined].

The male type was not dissected, however, a female from French Guiana (Fig. 17), in USNM, that was compared with, and matched the type has genitalia (Fig. 29) identical to those of C. mediana. It is very likely that after study of more material it will be proved that they all belong to one species.

\section{Cyphacma Meyrick, 1915}

Cyphacma Meyrick, 1915: 213. Type-species: C. chalcozela Meyrick, 1915: 213, by monotypy.

Described in the Heliodinidae, included in the Schreckensteiniadae [=Heliodinidae] by FLETCHER (1929: 63), in the Oecophoridae by HODGES (1983: 14) and transferred to the Stathmopodini [=Stathmopodinae] (Oecophoridae) by HEPPNER (1987: 5). C. chalcozela, the only species in the genus, is a very small, metallic, brilliant blackish moth, with very narrow hind wings, that resembles Metallocrates Meyrick, another cosmopterigid genus also originally described in the Heliodinidae (see below). It was described from a series of 14 specimens from different localities, therefore it might represent more than one species. There is a series in VOB that matches the type series, which, if not conspecific, it is congeneric. A pair of them were dissected and their genitalia resemble those of some species currently included in Anoncia Clarke (Cosmopterigidae).

\section{Dasycarea Zeller, 1877}

Fig. 16

Dasycarea Zeller, 1877: 373 . Type-species: $D$. viridisquamata Zeller, $1877: 373$, by monotypy.

Originally described in the Gelechiidae, this monotypic genus was transferred to Amphiteridae [=Roeslerstammiidae] by HEPPNER (1984: 25). D. viridisquamata, described from a single female from Colombia, with abdomen missing (Fig. 16), belongs to a complex of mostly Andean species currently in the Acrolepiidae. Its generic placement depends on discovery of further material for study of genitalia characters. With the exclusion of this genus from Roeslerstammiidae, this family is deleted from the New World Fauna.

\section{Ecballogonia Walsingham, 1912}

Figs 22, 30-32

Ecballogonia Walsingham, 1912: 137. Type-species: Ecballogonia bimetallica Walsingham, 1912: 138, by original designation.

Harpograptis Meyrick, 1925: 126. Type-species: Stomopteryx eucharacta Meyrick, 1922b: 66, by original designation. syn.n.

Revta bras. Zool. 16 (Supl. 2): 141 - 170, 1999 


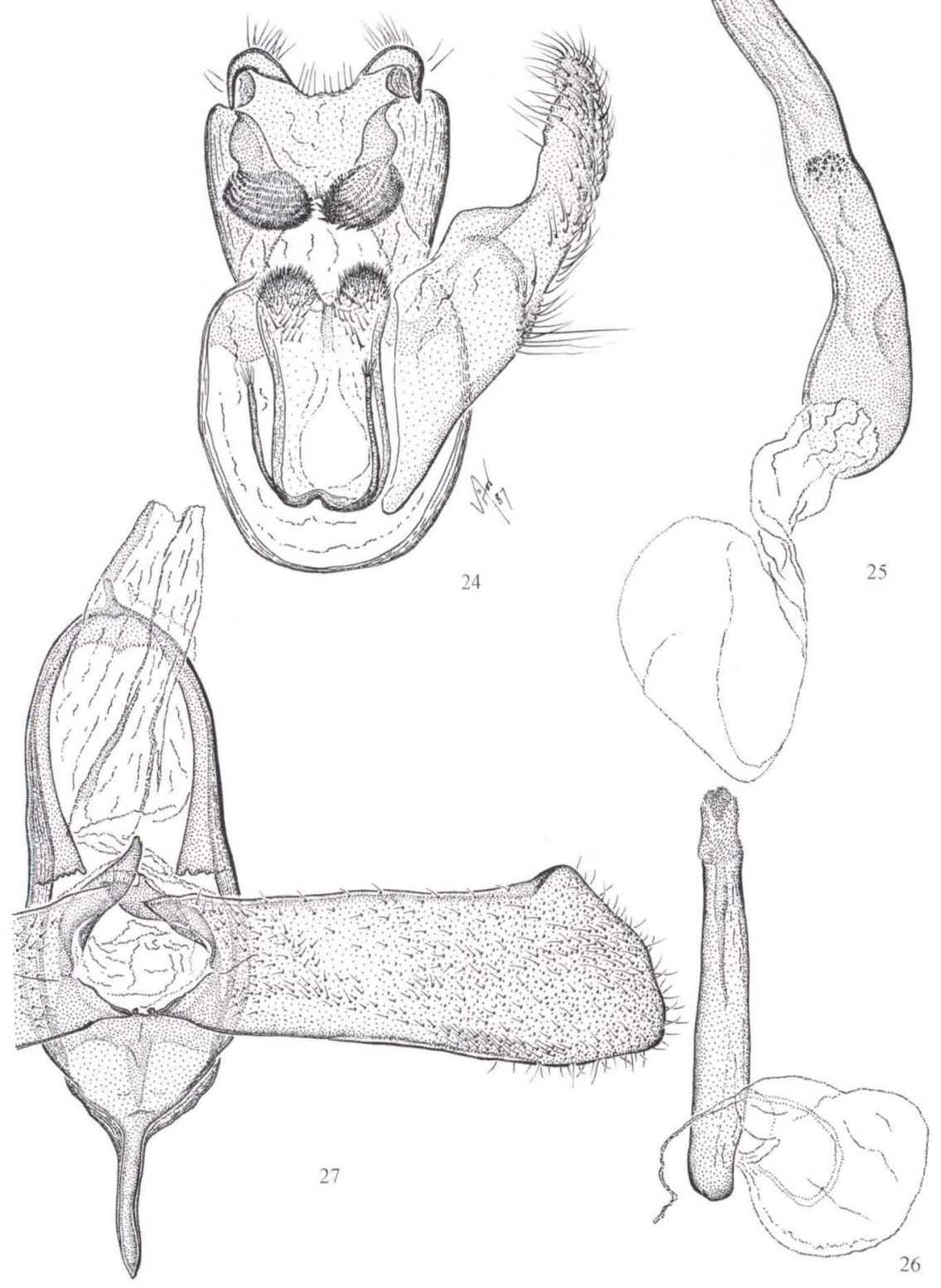

Figs 24-27. (24-25) Male genitalia of Amblytenes lunatica, holotype: (24) genitalia with left valva and aedoeagus removed; (25) aedoeagus; (26-27) Male genitalia of Cotaena mediana: (26) aedoeagus; (27) genitalia with left valva and aedoeagus removed. 

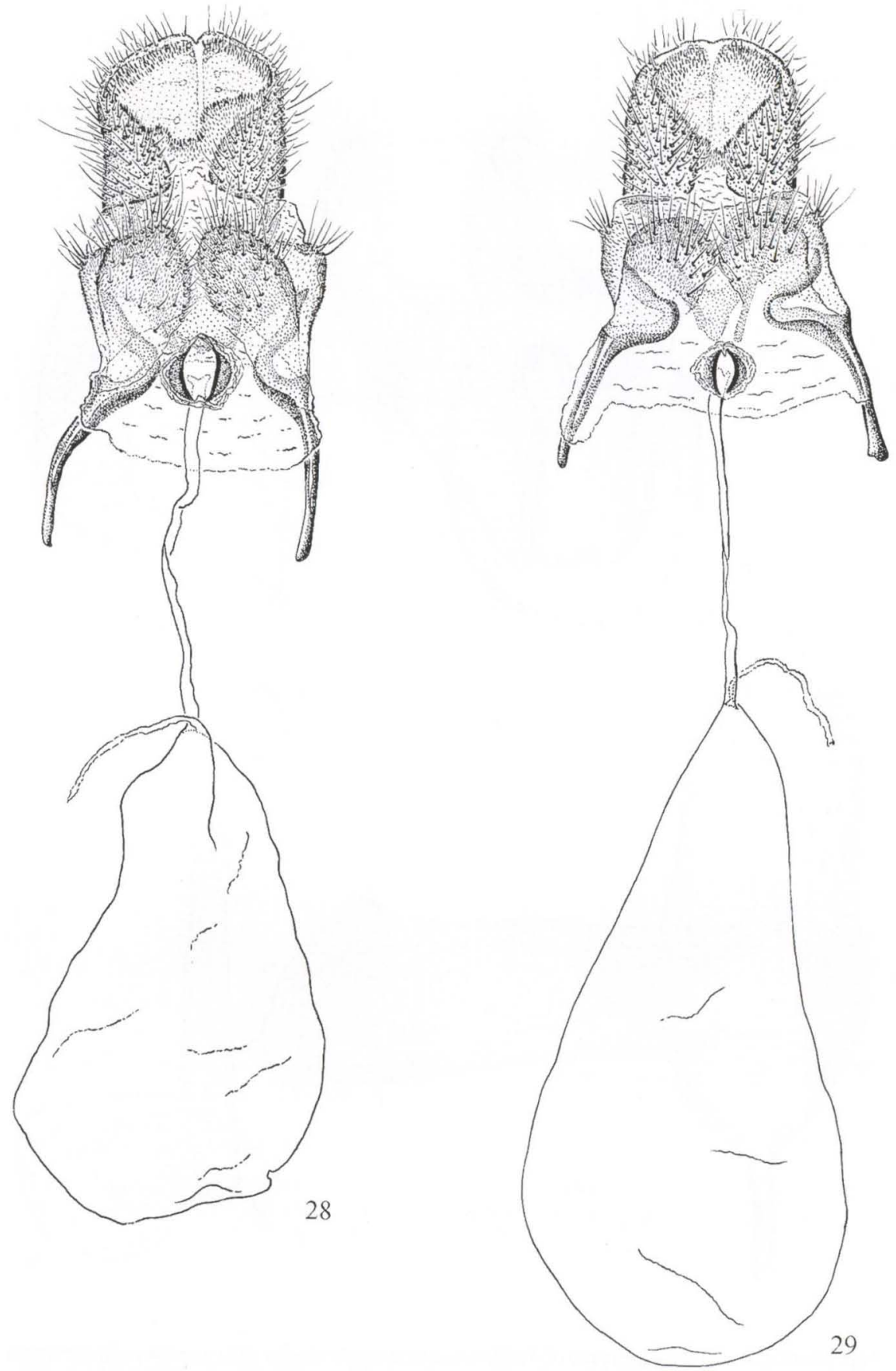

Figs 28-29. Female genitalia of Cotaena. (28) C. mediana; (29) C. phlegyropa. 
Ecballogonia, a monotypic genus, was originally described in the Oecophoridae, transferred to the "Schreckensteiniadae" [=Heliodinidae], by FLETCHER (1929: 72) and to the Cosmopterigidae by Hodges (1978: 53). Harpograptis, also monotypic, was originally included in the Gelechiidae and transferred to the Cosmopterigidae by CLARKE (1955: 21).

There are four males from Mexico in VOB (69041), one of them (Fig. 22) was compared with, and matched, the type of E. bimetallica in BMNH. Its genitalia (Figs 30-32) are very similar to those of E. eucharacta (Meyrick), comb.n., illustrated in CLARKE (1965: pl. 247, fig. 1c). This genus is closely related to Triclonella Busck, as stated by HoDGES (1978: 53).

\section{Echinophrictis Meyrick, 1922}

Figs $5,33,34$

Echinophrictis Meyrick, 1922a: 588. Type-species: E. triphracta Meyrick, 1922a: 588, by monotypy.

Originally described in the Heliodinidae, this monotypic genus was included in the Schreckensteiniadae [=Heliodinidae] by FLETCHER (1929: 73), and transferred to the Stathmopodini [Stathmopodinae] (Oecophoridae) by HEPPNER (1987: 5). One male (VOB 57562) (Fig. 5) was compared with, and matched the type of $E$. triphracta in BMNH; its genitalia (Figs 33,34) indicates that it belongs to the Momphinae (Coleophoridae).

\section{Euclemensia Grote, 1878}

Figs 19, 37

Hamadryas Clemens, 1864: 422. Type-species: H. bassettella Clemens, 1864: 423, by monotypy. Preoccupied by Hamadryas Hübner, [1806] (Nymphalidae).

Euclemensia Grote, 1878: 69. Type-species: H. bassettella Clemens, 1864: 423, by monotypy [of Hamadryas], replacement name.

Sisyrotarsa Meyrick, 1937: 89. Type-species: S. caminopa Meyrick, 1937: 89, by monotypy. syn.n.

Sisyrotarsa was originally described in the Heliodinidae and transferred to the Stathmopodini [Stathmopodinae] (Oecophoridae) by HEPPNER (1987: 5). The genitalia (Fig. 37) are congeneric with those of other species currently in Euclemensia.

\section{Euclemensia caminopa (Meyrick), comb.n.}

Fig. 19

Sisyrotarsa caminopa Meyrick, 1937: 89. Holotype female, TRINIDAD: St. Augustine, 24.VI.1935.

(O'Connor) (BMNH) [examined].

This is a beautifull species, with forewings indigo-blue with grimson-red markings. The specimen (Fig. 19) is in good condition except for the palpi and antennae which are missing, and for the thorax which is blown by oxidation of the brass pin. 

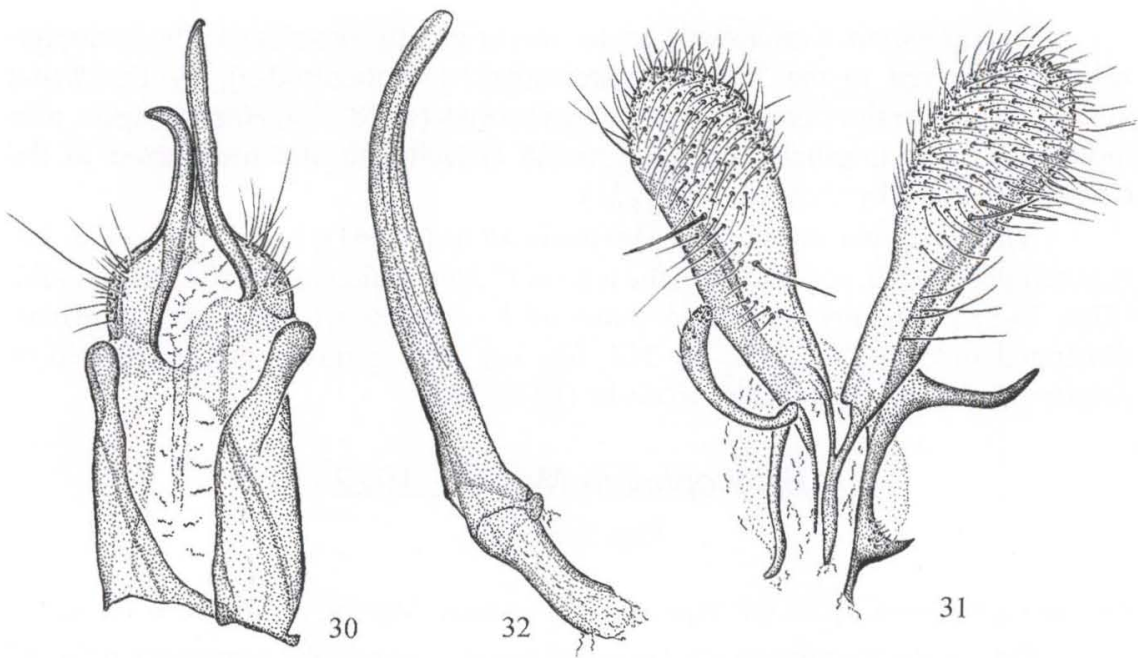

Figs 30-32. Male genitalia of Ecballogonia bimetallica. (30) tegumen-uncus; (31) valvae; (32) manica with aedoeagus in situ.

\section{Glyphidocera Walsingham, 1892}

Figs $38-40$

Glyphidocera Walsingham, 1892: 531. Type-species: G. audax Walsingham, 1892: 531, by original designation.

Ptilostonychia Walsingham, 1911: 109. Type-species: P. plicata Walsingham, 1911: 109, by original designation. syn.n.

Ptilonostychia Fletcher, 1929: 191. Misspelling.

Stibarenches Meyrick, 1930a: 228. Type-species: S. bifissa Meyrick, 1930a: 229, by monotypy. syn.n.

These monotypic synonyms were originally described in the Gelechiidae. Walsingham (1911: 109), recognized that Ptilostonychia was closely related to Glyphidocera and justified its proposal by the labial palpi thickenly scaled, a character later found in other species in Glyphidocera. The male genitalia (Figs 38, 39 ) of a specimen compared with, and matching the type of G. plicata (Walsingham), comb.n. are similar to those of other species in the genus. The female genitalia (Fig. 40) of the type-specimen of G. bifissa (Meyrick), comb.n. are also similar to those of other species currently in Glyphidocera. It is closely related to G. indocilis Meyrick, 1930a, another species, described from males, collected at the same locality: BRAZIL: [PA], Taperinha.

\section{Gnamptonoma Meyrick, 1917}

Fig. 1

Gnamptonoma Meyrick, 1917: 65. Type-species: G. leptura Meyrick, 1917: 65, by monotypy.

Originally described in the Heliodinidae and included in the Schreckensteiniadae [=Heliodinidae] by FLETCHER (1929: 100), this monotypic genus was 
transferred to the Stathmopodini [Stathmopodinae] (Oecophoridae) by HEPPNER (1987: 5). G. leptura (Fig. 1) is a small moth with very narrow wings resembling species of Batrachedra Herrich-Schäffer and Tetanocentria Rebel. The type has not been dissected, however, a female in VOB (46432) that matches the type, has genitalia similar to those of species currently in Tetanocentria. The abcence of spines on the terga places it in the Agonoxeninae (Elachistidae).
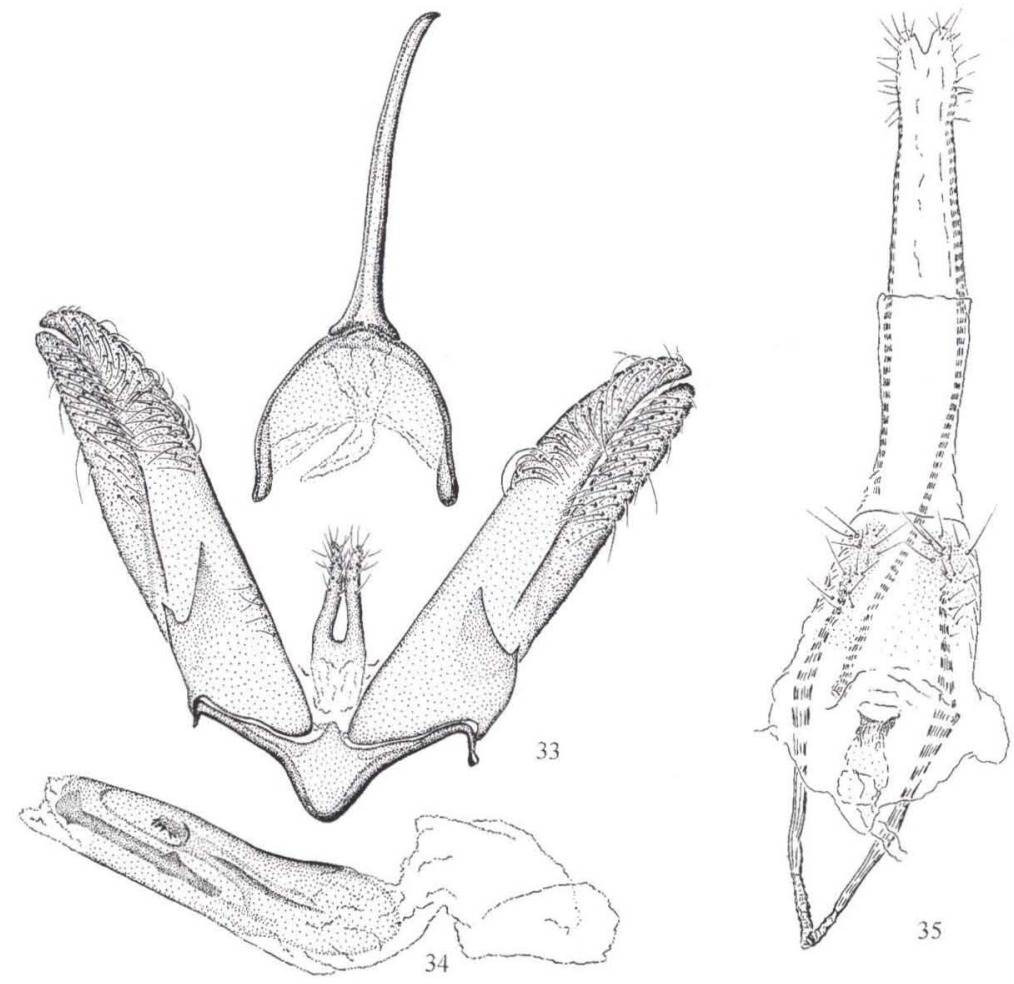

Figs 33-35. Genitalia of Momphinae (Coleophoridae). (33-34) Male of Echinophrictis triphracta, (33) genitalia with tegumen-uncus detached, and aedoeagus removed; (34) aedoeagus; (35) Female of Palaeomystella chalcopeda, holotype, (bursa copulatrix missing in preparation).

Metallocrates Meyrick, 1930

Fig. 23

Metallocrates Meyrick, 1930b: 579. Type-species: M. transformata Meyrick, 1930b: 579, by monotypy. Magorrhabda Meyrick, 1932: 273. Type-speces: M. elytrata Meyrick, 1932: 273, by monotypy. syn.n.

Metallocrates was described in the Blastobasidae, Magorrhabda in the Heliodinidae, and tranferred to the Stathmopodini [=Stathmopodinae] (Oecophoridae) by HEPPNER (1987: 5). The type-specimens of both type-species of these 
monotypic genera were examined. The genitalia of $M$. elytrata $[=M$. transformata $]$ leave no doubt that it belongs to the Cosmopterigidae (see below). It resembles Cyphacma Meyrick, also described originally in the Heliodinidae (see above). Metallocrates transformata (Fig. 23) is larger and has broader hind wings than Cyphacma, with venation, as illustrated by CLARKE (1963: pl. 243, figs 1, la) similar to that of Triclonella, as figured in HODGES (1978: fig. 2b).

\section{Metallocrates transformata Meyrick, 1930}

Fig. 36

Metallocrates transformata Meyrick, 1930b: 579. Holotype male, BRAZIL: AM, Tefé (Parish) (BMNH) [examined].

Magorrhabda elytrata Meyrick, 1932: 273. Lectotype female: PERU: Iquitos, III.1920 (Parish) $(\mathrm{BMNH})$, here designated [examined]. syn.n.

Metallocrates transformata was described from a unique male which has the abdomen missing and M. elytrata from two females from the same locality. Their shape, colour and wing venation match. Undoubtedly both taxa were described from the opposite sexes of the same species. The genitalia of the lectotype of $M$. elytrata are illustrated here for the first time (Fig. 36).

\section{Nicanthes Meyrick, 1928}

Figs $6,43,44$

Nicanthes Meyrick, 1928: 395. Type-species: Nicanthes rhodoclea Meyrick, 1928: 395, by monotypy.

Originally described in the Cosmopterigidae, this monotypic genus was transferred to the Blastodacninae [=Parametriotinae] (Elachistidae) by BECKER (1984a: 43), following Meyrick's remark that it was related to Pammeces Zeller, a genus currently placed in this subfamily. HODGES (1997: 272) suspected that it might belong to the Gelechiinae, what is here confirmed by the characters of the male genitalia (Figs 43, 44). This conspicuous pink moth with yellow forewings (Fig. 6), was represented, until recently, by the type and five specimens, one from PUERTO RICO, and four from BRAZIL, in VOB. In a single night the author collected a series of 58 specimens in BRAZIL: BA, Camamu, Barra Grande, 2 m, 6.I.1999, in an open grassy area next to a disturbed costal forest. The female type is illustrated, including wing venation and genitalia, in CLARKE (1965: 515, pl. 253, figs 1-1d).

\section{Palaeomystella Fletcher, 1940}

Fig. 35

Palaeomystis Meyrick, 1931: 55. Type-species: P. chalcopeda Meyrick, 1931: 55, by monotypy. Preoccupied by Palaeomystis Warren, 1894 [Geometridae].

Palaeomystella Fletcher, 1940: 18. Type-species: Palaeomystis chalcopeda Meyrick, 1931: 55, by monotypy [of Palaeomystis], replacement name.

Palaeomystis, a monotypic genus, was originally included in the Cosmopterigidae and transferred to the Agonoxenidae by HEPPNER (1984: 58) in an addendum to the Gelechioidea by BECKER (1984a: 27-58). The type-specimen of P. chalcopeda (MNHN, ex Col. Joannis), was examined in 1985, after the publica- 


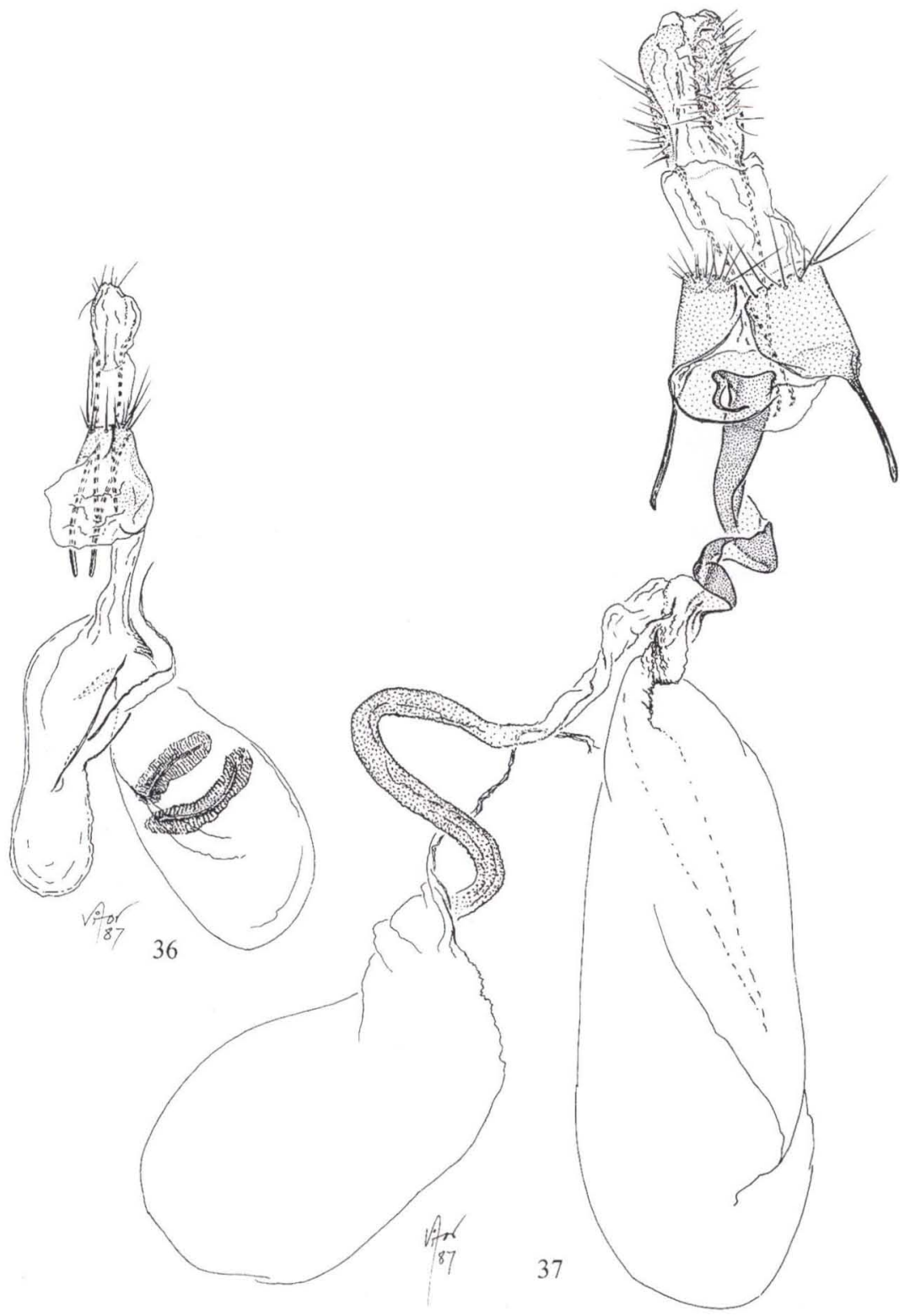

Figs 36-37. Female genitalia of Cosmopterigidae. (36) Metallocrates transformata [lectotype of M. elytrata]; (37) Euclemensia caminopa, holotype.

tion of the Atlas (HEPPNER 1984). The specimen is a female, with the genitalia damaged (Fig. 35). The ramaining characters do not allow a clear conclusion about its placement, however, some species which have been reared by the author from 

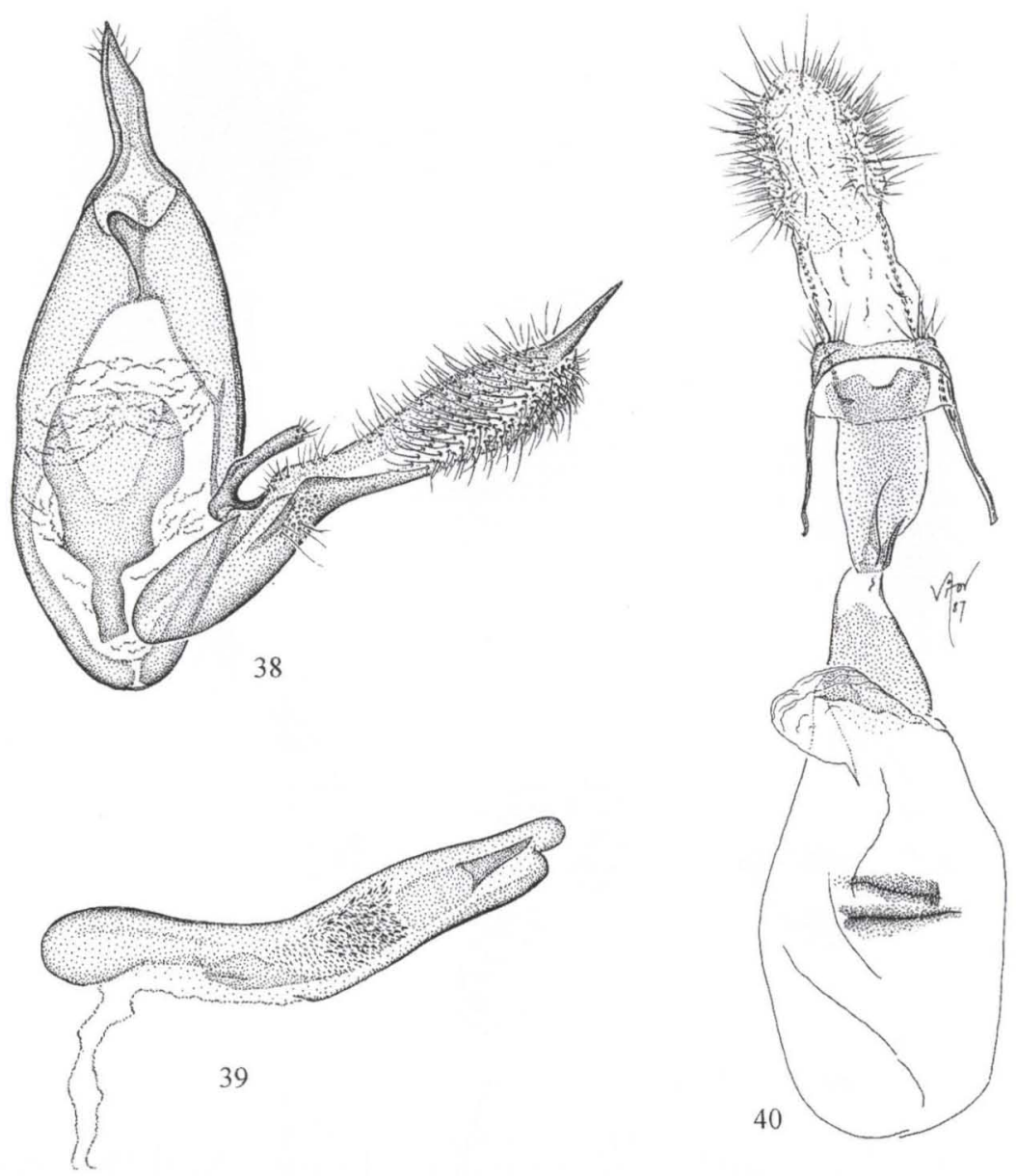

Figs 38-40. Genitalia of Glyphidocera. (38-39) Male of G. plicata, (38) genitalia with left valva and aedoeagus removed; (39) aedoeagus; (40) female of $G$. difissa, holotype.

galls found on several species of Melastomataceae, are undoubtedly congeneric with $P$. chalcopeda and their male genitalia indicates that they are true Momphinae (Coleophoridae).

TAVARES (1917: 31, pl. 1, figs 1,2) described and illustrated a gall collected by him on Tibouchina sp. (Melastomataceae), from BRAZIL: RJ, Petrópolis, Tijuca and Nova Friburgo [the last is also the type-locality of chalcopeda]. According to him the gall-maker was a small moth whose description suggests that it could be $P$. chalcopeda. The same galls were seen at Itatiaia National Park, Rio de Janeiro, but unfortunately the author did not have the necessary permits to collect some. This species is being treated in a forthcoming paper dealing with several cecidogenous Momphinae species reared from Melastomataceae species from Brazil. 

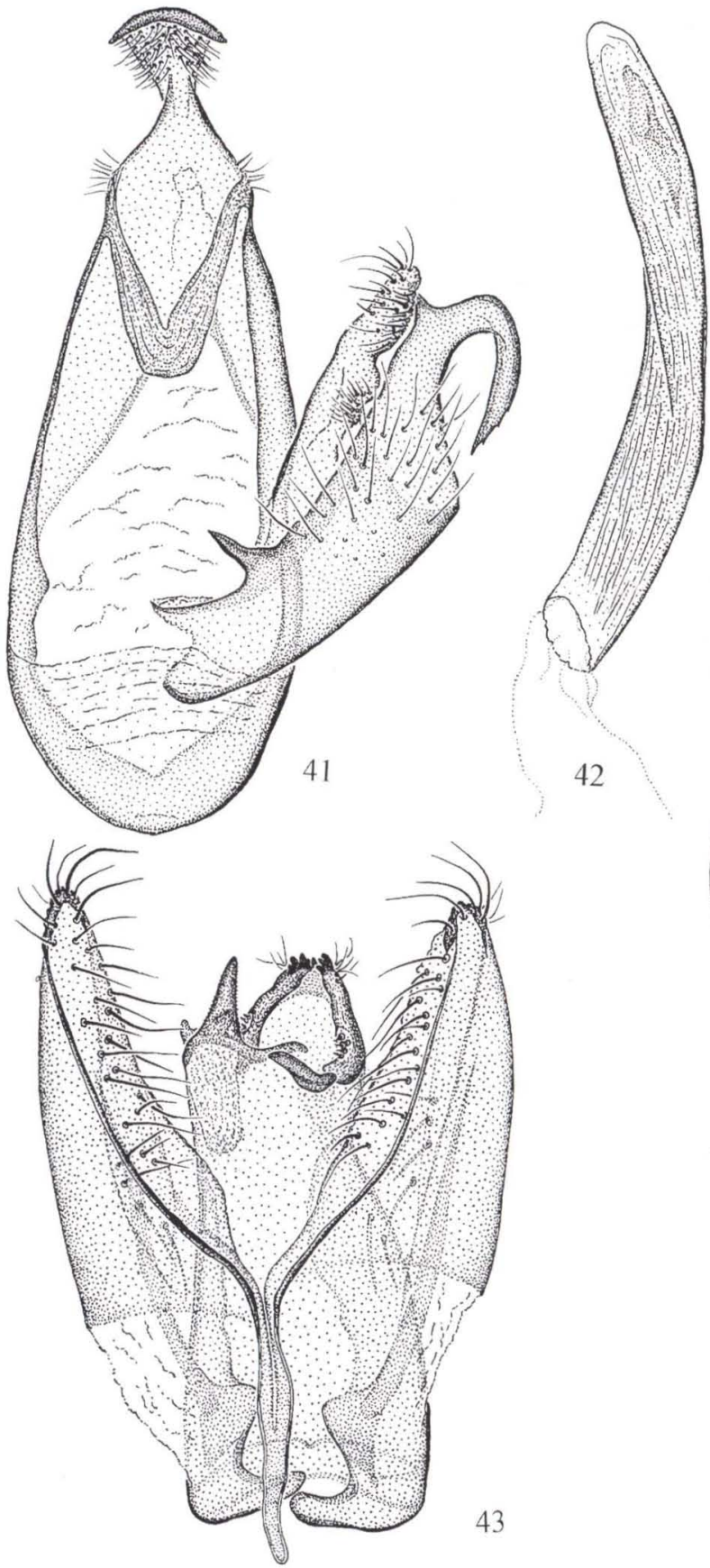

42

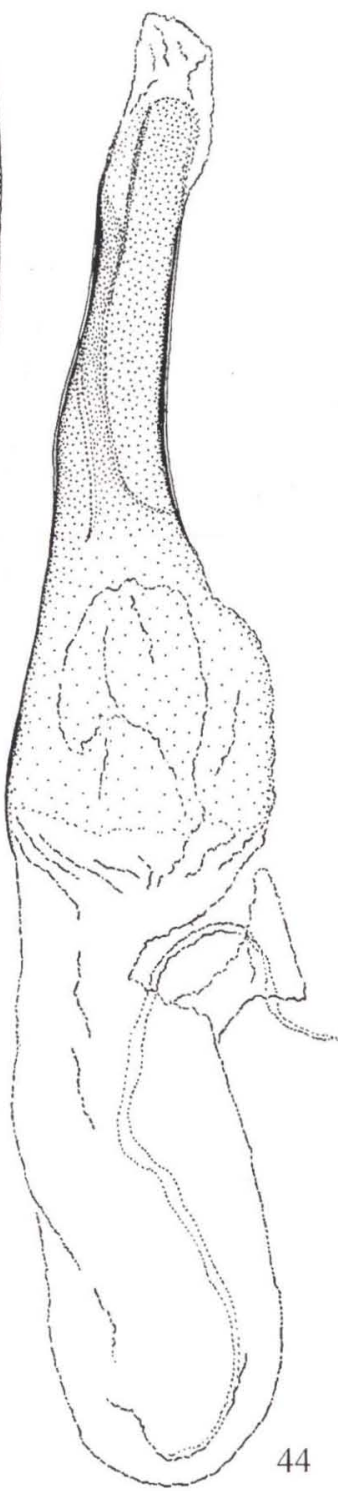

Figs 41-44. Male genitalia of (41-42) Elachistidae and (43-44) Gelechiidae. (41-42) Pammeces picticornis, (41) genitalia with aedoeagus removed, (42) aedoeagus (43-44) Nicanthes rodochlea, (43) genitalia with aedoeagus removed, (44) aedoeagus. 

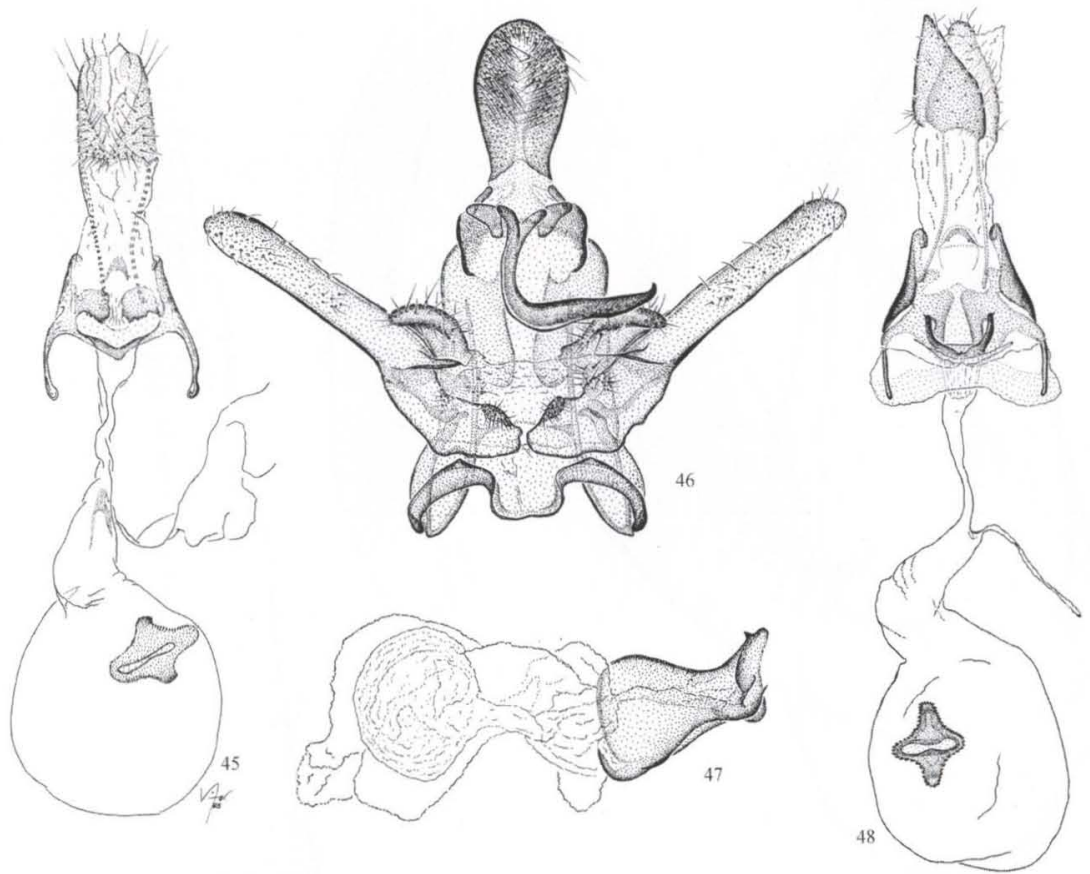

Figs 45-48. Genitalia of Percnarcha. (45) Female of $P$. strategica, holotype; (46-48) $P$. trabeata. (46) male with aedoeagus removed, (47) aedoeagus; (48) female.

\section{Pammces picticornis (Walsingham, 1897), comb.n. Figs $2,41,42$}

Coleophora picticornis Walsingham, 1897: 102. Syntypes: HAITI: Port-au-Prince, 23.v. (Gudmann); GRENADA: Balthazar, 15.iv (H. H. Smith) (BMNH) [examined].

There is a series of 20 specimens in VOB from Puerto Rico and the Virgin Islands and one them (Fig. 2) was compared, and matched, the type in BMNH. The genitalia (Figs 41, 42), and the absence of spines on terga indicates that it belongs to Agonoxeninae (Elachistidae).

The holtype of $P$. albivittella Zeller, the type-species of Pammeces, and the only specimen known, has the abdomen missing. Therefore, the placement of $P$. picticornis in this genus is dubious, and was included here as it resembles other species currently in the genus.

\section{Percnarcha Meyrick, 1915}

Percnarcha Meyrick, 1915: 212. Type-species: Tinaegeria trabeata Meyrick, 1909: 18, by original designation.

This genus was originally described in the Heliodinidae, intluded in the Schreckensteiniadae [=Heliodinidae] by FLETCHER (1929: 168), and transferred to the Stathmopodini [Stahtmopodinae] (Oecophoridae) by HEPPNER (1987: 5). Des- 


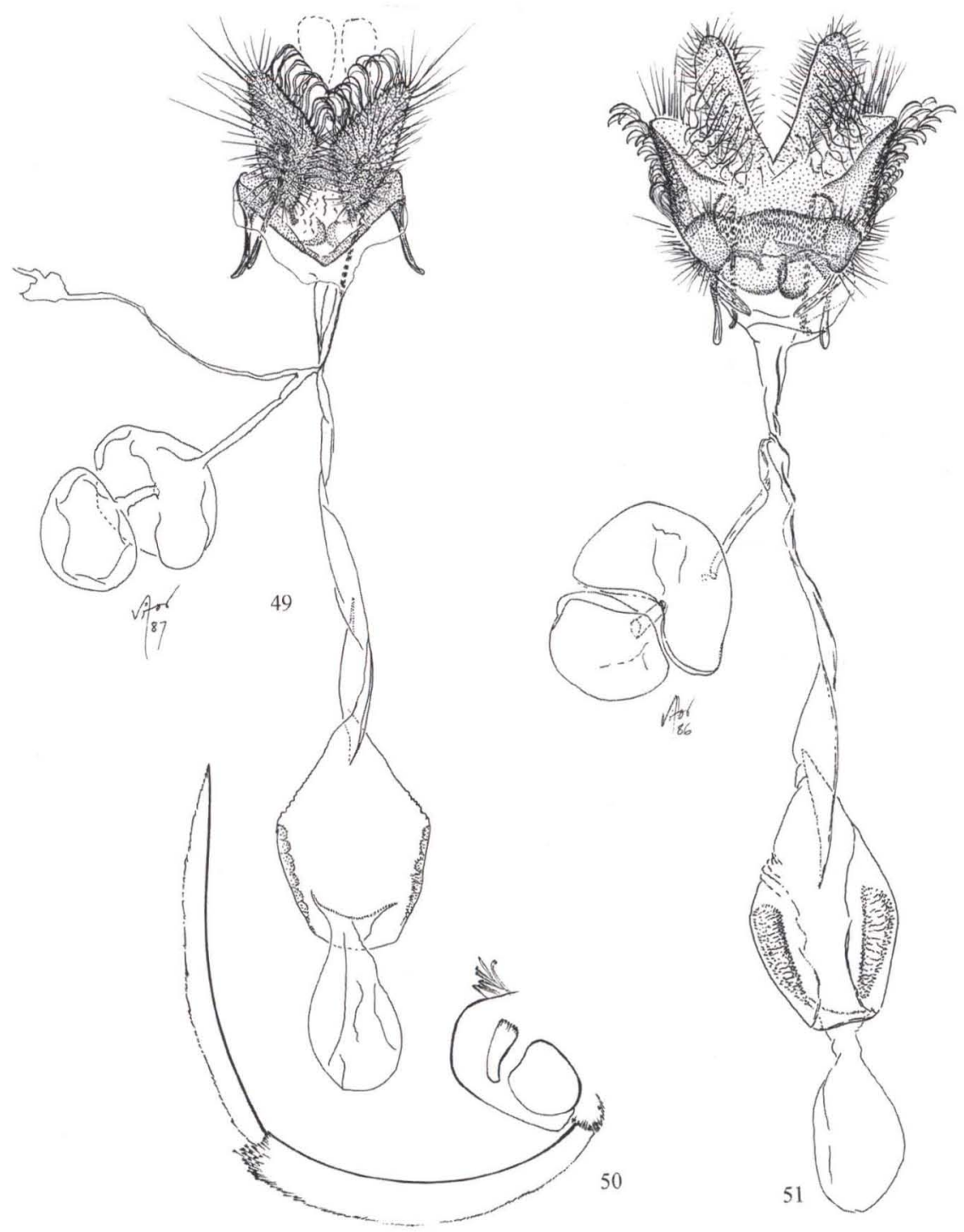

Figs 49-51. Tinaegeria. (49) Female genitalia of T. basalis, holotype; (50-51) T. tunicata, holotype, (50) head, lateral view; (52) female genitalia.

pite its unusual pattern (Figs 12, 14), the wing venation, and the genitalia (Figs 45-48) places it in the Gelechiidae. This is the only gelechiid genus in the New World whose species mimics some Sesiidae and Tinaegeria species (Oecophoridae). 


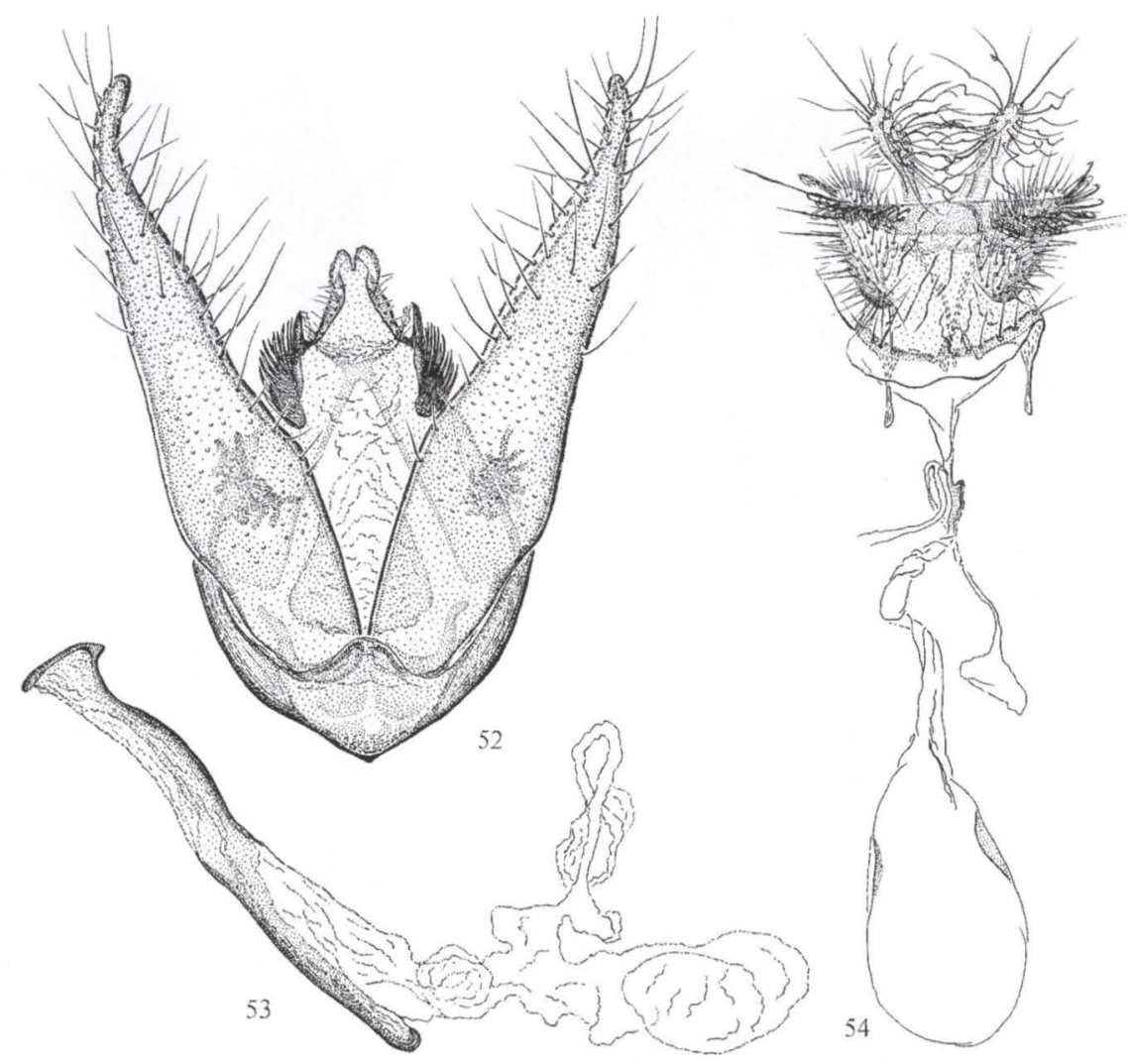

Figs 52-54. Genitalia of Tinaegeria nephelozyga. (52) male with aedoeagus removed, (53) aedoeagus; (54) female, holotype.

\section{Percnarcha latipes (Walker, [1865]), comb.n.}

Fig. 14

Tinaegeria latipes Walker, [1865]: 25. Holotype female: [BRAZIL: PA], Belém ["Pará”] (Bates] (BMNH) [examined].

The type (Fig. 14) is in good condition, except for the missing abdomen. The wing venation matches that of other species of Percnarcha. This species was included by WALSINGHAM (1889: 16) in his genus Snellenia, a true Stathmopodinae (COMMON 1990: 225), which species, except for this, are restricted to the Australian region. [S. flavipennis (Felder \& Rogenhofer, 1875, pl. 138, fig. 59), described from a specimen of dubious provenance ["Amer. ?"], is, according to WALSINGHAM (1889: 9) closely related to $S$. sesioides (Walker), from Australia, and consequently has been excluded from the neotropical fauna (BECKER 1984b: 260]. With the exclusion of $P$. latipes from Snellenia, this genus is consequently eliminated from the New World fauna. 


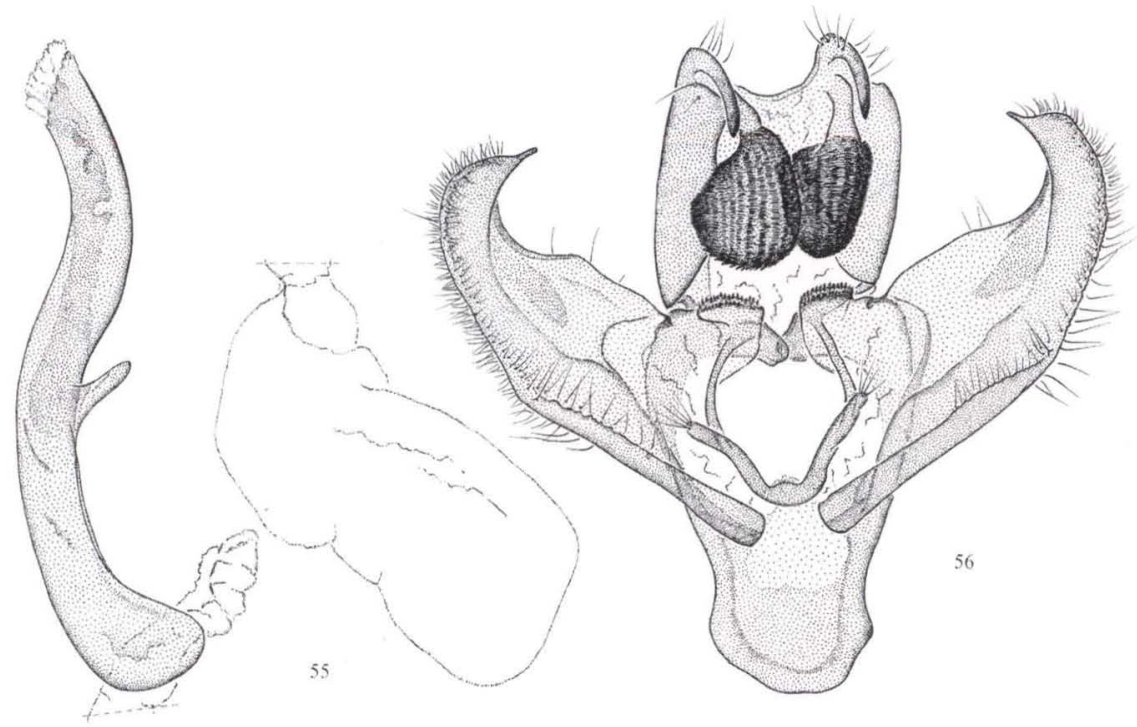

Figs 55-56. Male genitalia of Tocasta priscella, paratype. (55) aedoeagus; (56) genitalia with aedoeagus removed.

\section{Percnarcha lilloi (Köhler, 1941), comb.n.}

Gaea lilloi Köhler, 1941: 6. Syntypes, 2 males: ARGENTINA: [Tucuman], Tucuman, no further data

(IML, UNLP) [not examined].

This species was originally described in the Aegeriidae [=Sesiidae] and transferred to the Gelechiidae, without specification of genus, by DUCKWORTH \& EICHLIN (1978: 16). A colour slide of one of the syntypes, kindly supplied by Dr. O. Mielke, Universidade Federal do Paraná, has been examined and showed that it is closely related to the other species currently in this genus.

\section{Percnarcha strategica Meyrick, 1930}

Fig. 45

Percnarcha strategica Meyrick, 1930a: 260. Lectotype female: BRAZIL: PA, Belém, 13-14.IX.1927, genit. slide 13328, VOB, (Zerny) (NM), here designated [examined].

The genitalia of the female type-specimen (Fig. 45) are almost identical to those of trabeata.

\section{Profilinota Clarke, 1973}

Ilarches Meyrick, 1933: 355. Type-species: I. notaula Meyrick, 1933: 355, by monotypy. Preoccupied by Ilarches Cantor, 1850 [Pisces]. Synonymized by NYE \& FLETCHER (1991: 159).

Profilinota Clarke, 1973: 100. Type-species: P. phillita Clarke, 1973: 100, by monotypy.

Ilarches was originaly described in the Gelechiidae; Profilinota in the Oecophoridae. The spined gnathos places it in the Depressariinae (Elachistidae) (see below). 

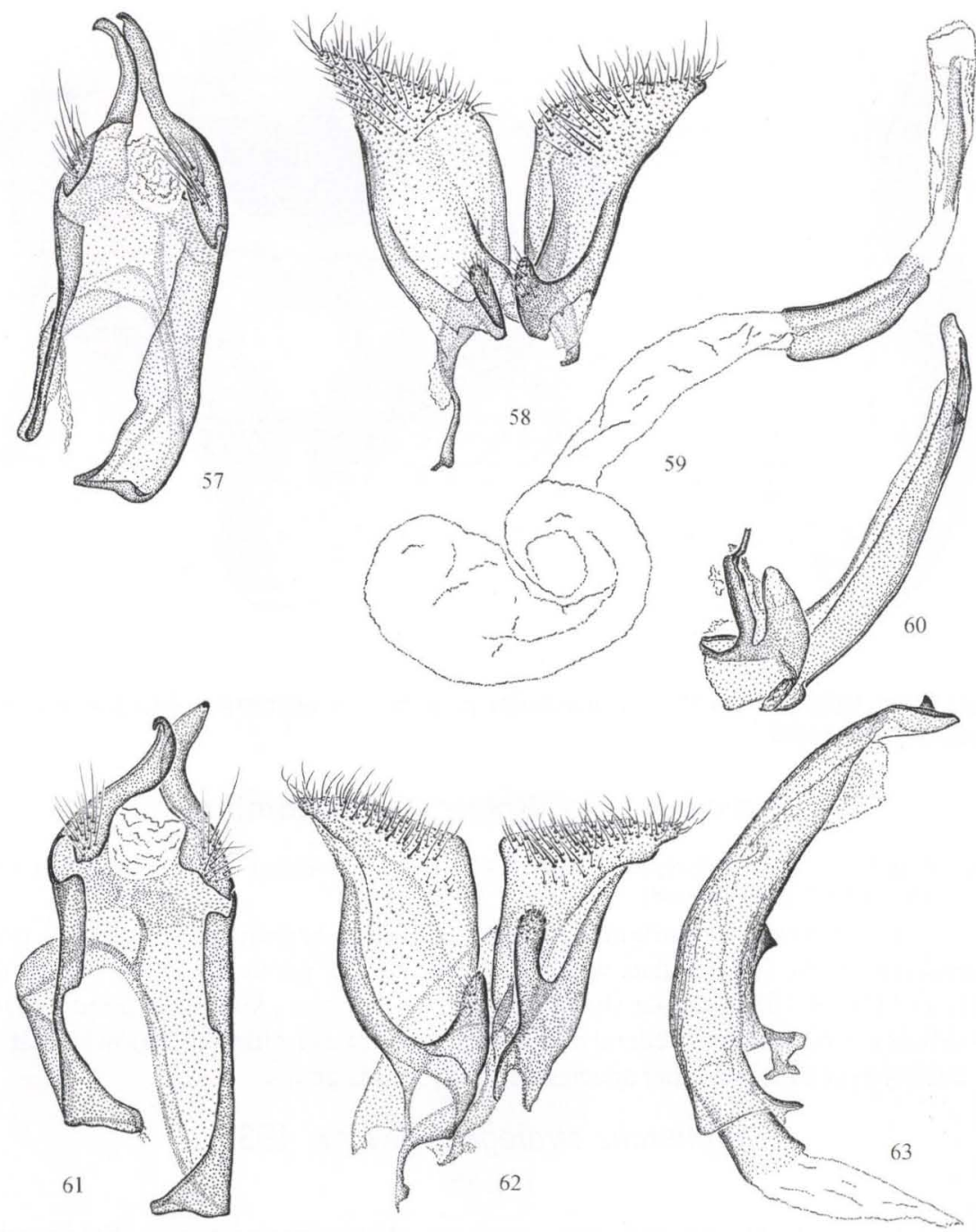

Figs 57-63. Male genitalia of Triclonella. (57-60) T. albicellata, (57) tegumen-uncus, (58) valvae, (59) aedoeagus, (60) manica; (61-63) T. citrocarpa, (61) tegumen-uncus, (62) valvae, (63) manica with aedoeagus in situ.

\section{Profilinota notaula (Meyrick, 1933), comb.n.}

Ilarches notaula Meyrick, 1933: 355. . Holotype male: BOLIVIA: R[io] Songo, 750m (NM) [examined]. Profilinota phillita Clarke, 1973: 102. Holotype male: VENEZUELA: Aragua, Rancho Grande, 31.XII.1966 (S.\& D. W. Duckworth) (USNM) [examined]. syn.n.

Both type-specimens, undoubtedly conspecific, are in good condition, and that of $P$. phillita is illustrated in CLARKE (1973: 100-101). 


\section{Stilbosis sexgutella (Walker, 1864), comb.n.}

Gelechia sexgutella Walker, 1864: 1021. Holotype "male": [BRAZIL: AM: Tefé] "Ega" (Bates) (BMNH) [examined].

Stilbosis chrysorrhabda Meyrick, 1922a: 576. Lectotype male: BRAZIL: AM, Rio Trombetas IX.1919 (Parish) (BMNH), designated by CLARKE 1965: 538 [examined]. syn.n.

Stilbosis sexgutella has been curated in BMNH along with other species of Heliodines. However no reference to this transfer was found. CLARKE (1965: 539, pl. 265, figs 2-2b) illustrated the adult and genitalia of the type of $S$. chrysorrhabda (Cosmopterigidae).

\section{Tinaegeria Walker, 1856 \\ Figs $9-11,13,18$}

Tinaegeria Walker, 1856: 260. Type-species: T. ochracea Walker, 1856: 260, by subsequent designation. Arauzona Walker, [1865]: 25. Type-species: A. basalis Walker, [1865]: 26, by monotypy. syn. rev. Machaerocrates Meyrick, 1931: 175. Type-species: M. tunicata Meyrick, 1931: 176, by monotypy. syn.n.

Tinaegeria and Arauzona were originally described in the Aegeriidae [ $=\mathrm{Se}-$ siidae], as their pattern (Figs 9-11, 13, 18), resemble those of sesiid moths. HAMPSON ([1893]: 206) erected the new family Tinaegeriidae [=Stathmopodinae] to accommodate Tinaegeria and other similar looking genera. WALSINGHAM (1889) revised the group and synonymized Arauzona under Tinaegeria, and illustrated in colour, among others, the type-species of both genera. In a later work (WALSINGHAM 1913: 202-204), he reversed his decision, revalidating Arauzona, and argued that Hampson's Tinaegeriidae could not be retained, transfering both genera back to the Aegeriadae [=Sesiidae]. Both genera were transferred to the Schreckensteiniadae [=Heliodinidae] by FLETCHER $(1929: 20,223)$ and to the Stathmopodini [ =Stathmopodinae] (Oecophoridae) by BECKER (1984a: 40).

Machaerocrates was originally described in the Heliodinidae and transferred to the Stathmopodini [=Stathmopodinae] (Oecophoridae) by HEPPNER (1987: 5). MEYRICK (1931: 176) pointed out in the original description that the labial palpi (Fig. 50) are "extremely long". They are so, however, not longer than those of other species of Tinaegeria. The genitalia of the female type of T. tunicata (Fig. 52) are also typically Tinaegeria, being almost identical to those of the female type [not a male as stated in the original description] of basalis (Fig. 49).

The male and female genitalia of $T$. ochracea were illustrated in a previous paper (BECKER 1984b: 263). Those of the female type of T. nephelozyga Meyrick [not a male as stated in the original description], currently in the MNHN, were also examined and are illustrated here for the first time (Fig. 54), together with those of a male from BRAZIL: RJ, Itatiaia (Zikán), currently in the FOC (Figs 52, 53 ). An updated list of the species of Tinaegeria stands as follows:

basalis (Walker, [1865]: 26) (Arauzona), comb. rev..

clitarcha Meyrick, 1921: 442

fasciata Walker, 1856: 261

croconympha Meyrick, 1921: 441, syn.n. 
moorei (Busck, 1913: 88) (Arauzona), comb.n.

nephelozyga Meyrick, 1930: 586

ochracea Walker, 1856: 260

aeneiceps (Felder \& Rogenhofer, 1875: pl. 138, fig. 62) (Eretmocera)

pyromantis Meyrick, 1921: 442

tunicata (Meyrick, 1931: 176), comb.n.

\section{Tocasta Busck, 1912}

Tocasta Busck, 1912: 4. Type-species: T. priscella Busck, 1912: 4, by original designation.

Diacholotis Meyrick, 1937: 79. Type-species: D. iopyrrha Meyrick, 1937: 79, by monotypy. syn.n.

The monotypic Tocasta was originally described in the Coleophoridae, transferred to Tineidae by FLETCHER (1929: 226) and back to Coleophoridae by BECKER (1984a: 42), and to Agonoxeninae (Elachistidae) by BALDIZzone (1989: 152). Diacholotis, also monotypic was established in the Cosmopterygidae [sic!] and transferred to the Agonoxenidae by HEPPNER (1984: 58), in an addendum to BECKER (1984a: 58). This genus is a true Parametriotini (Agonoxeninae, Elachistidae), closely related to Amblytenes Meyrick and Nanodacna Clarke. In T. priscella the vinculum is expanded into a broad saccus (Fig. 56), whereas in the other two genera it is thin and rounded.

\section{Tocasta priscella Busck, 1912}

Figs 55,56

Tocasta priscella Busck, 1912: 4. Lectotype male: PANAMA: Cabima, V.1911 (Busck) (USNM), here designated [examined].

Diacholotis iopyrrha Meyrick, 1937: 79. Holotype male: COSTA RICA: [Cartago: Turrialba], Rio Reventazón, F. [arm] Hamburg, 31.III.1932 (Nevermann) (NM) [examined]. syn.n.

The male genitalia of both type-specimens are almost identical [the type-specimen of $D$. iopyrrha is a male, not a female as stated in the original description]. The illustrations presented here (Figs 55, 56) were based on a paralectotype of $T$. priscella. "Farm Hamburg" is the place where the IICA graduate school and research center (CATIE) is located today.

\section{Triclonella albicellata (Meyrick, 1931), comb.n.}

Figs 20, 57-60

Scaeosopha albicellata Meyrick, 1931: 118. Holotype male, BRAZIL: [Ba]: Sta. Rita bis Parangua, 1.V.1903 (Penther) (NM) [examined].

The genus Scaeosopha was originally described in the Oecophoridae, and transferred to the Cosmopterigidae by CLARKE (1955: 21). T. albicellata and $T$. citrocarpa [see below] belong to a complex of closely similar, beautifully marked forms (Figs 20,21), dark gray with orange and whitish markings on fore wings. Their genitalia (Figs 57-60), similar to those of others species currently placed in the New World genus Triclonella Busck, are not congeneric with those of Scaesopha Meyrick (see illustrations in CLARKE 1965: pls. 261, 262), a genus apparently

Revta bras. Zool. 16 (Supl. 2): 141 - 170, 1999 
restricted to India and Indonesia. There is a series of specimens from BRAZIL: DF, GO, MT $(19372,19678,22227,59276,89275)$ which were compared, and matched the type of $T$. albicellata.

\section{Triclonella citrocarpa (Meyrick, 1931), comb.n.}

Figs 21, 61-63

Scaeosopha citrocarpa Meyrick, 1931: 118. Holotype male, BRAZIL: [ES], [Baixo] Guandu, 1920 (Hoffmann) (NM) [examined].

This and $T$. albicellata are very closely related and could be only geographic forms of the same species. They show slight differences in the male genitalia (Figs 61-63) and in T. citrocarpa (Fig. 21) the fore wings have an orange mark at the end of cell. The type specimen is in a very poor condition, with the head and left fore wing missing. There is a series of specimens from BRAZIL: MS, SC in VOB (11496, $11557,13092,13176,17258,52003$ ) which were compared, and matched, the type.

With the transfer of these two species to Triclonella, the genus Scaeosopha has no representative in the New World fauna.

\section{Triclonella mediocris (Walsingham, 1897), comb.n.}

Fig. 4

Pigritia mediocris Walsingham, 1897: 94. Syntypes: VIRGIN IDS: St. Thomas, 12.III (Gudmann) (BMNH) [examined].

Triclonella rhabdophora Forbes, 1930: Holotype, VIRGIN IDS: St. Thomas, Coaling Dock, 24.III.1927

(CU) [not examined]. syn.n.

Pharmacoptis breviramis Meyrick, 1932: 277. Syntypes, VIRGIN IDS: St. Thomas, III.IV. (Gudmann) (NM) [not examined]. syn.n.

There is a series of 14 specimens in VOB from the BVI: Guana Id. (66819, 70967) (Fig. 4) and one from PuerTo Rico: Guanica (67852). The Puerto Rican specimen was compared with, and matches, the paratypes of $T$. rhabdophora in USNM, and the syntypes of T. mediocris in BMNH. P. breviramis had been synonymized with $T$. rhabdophora (HoDGES 1978: 52). It Is very likely that the type-series of $T$. breviramis originally belonged to part of the type-series of $T$. mediocris as both were collected in St. Thomas by the same collector. The genitalia of both sexes of these Antillean specimens show no difference to those of $T$. bicoloripennis Hodges, from southern USA, as illustrated in HoDGES (1978: 80, fig. $11 \mathrm{~b}, 93$, fig. $24 \mathrm{~g})$.

ACKNOWLEDGEMENTS. The author is most gratefull, to the following coleagues for permission to study material under their care: Don R. Davis and Ron W. Hodges (USNM), O. V. Ferreira (FOC), Fritz Kasy (NM), James Liebherr (CU), Gérard Luquet (MNHN), Christopher O'Toole (UMO), Klaus Sattler (BMNH); to Kevin Tuck (BMNH) for providing colour slides of some type-specimens, to Frederick W. Stehr (Michigan State University) for reading the manuscript, to Jean-François Landry (Agriculture Canada, Ottawa) for providing some bibliography, to Antônio L. L. Gomes and Carlos A. Braga (EMBRAPA-CPAC, Planaltina, $\mathrm{DF}$, Brazil) for collecting and spreading part of the material, and, especially, to Wellington Cavalcanti (EMBRAPA-CPAC), for producing part of the line drawings. 


\section{REFERENCES}

BALDizzonE, G. 1989. Contribuzioni alla conoscenza del Coleophoridae. LVIII. Nuove sinonimie nel genere Coleophora Hübner (VII) (Lepidoptera). Revta piemont. Stor. Nat. 10: 145-154.

BECKER, V.O. 1984a. Gelechioidea, p. 27-53. In: J.B. HEPPNER (Ed.). Atlas of Neotropical Lepidoptera Checklist: Part 1. The Hague, W. Junk.

. 1984b. The Neotropical Gelechioidea (Lepidoptera) described by Cajetan

Felder \& Alois R. Rogenhofer. Syst. ent. 9: 245-280.

BoIsDUVAL, J.B.A.D. DE. [1875]. Sphingides, sesiides, castniides. In: J.B.A.D. DE

Boisduval \& A. GuenÉe (Ed.). Histoire naturelle des insectes: Spécies

général des Lépidotères hétérocères. I. Paris, Roret, $568 \mathrm{p}$.

BUSCK, A. 1912. Descriptions of new genera and species of Microlepidoptera from

Panama. Smith. misc. Collns 59: 1-10.

- 1913. New Microlepidoptera from British Guiana. Insec. Inscit. mens. 1: $88-92$.

Clarke, J.F.G. 1955. Catalogue of the type specimens of Microlepidoptera in the British Museum (Natural History) described by Edward Meyrick. I. London, British Museum (Natural History), 332p.

. 1963. Catalogue of the type specimens of Microlepidoptera in the British Museum (Natural History) described by Edward Meyrick. IV. London, British Museum (Natural History), 521p.

. 1965. Catalogue of the type specimens of Microlepidoptera in the British Museum (Natural History) described by Edward Meyrick. V. London, British Museum (Natural History), 581p.

.1973. A new genus and species of Oecophoridae from Tropical America. Jour. Lepidop. Soc. 27: 99-102.

Clemens, B. 1864. North American Microlepidoptera. Proc. ent. Soc. Philad. 2: 415-430.

Common, I.F.B. 1990. Moths of Australia. Carlton, Victoria, Melbourne Universtity, 535p.

DUCKWORTH, W.D. \& T.D. EICHLIN. 1978. The type-material of Central and South American clearwing moths (Lepidoptera: Sesiidae). Smith. contr. zool. 261: $1-28$.

FELDER, C. \& A.F. RogENHOFER. 1875. Reise der österreischischen Fregatte Novara um die Erde (Zoologischer Theil), 2, Abtheilung 2) Heft 4: pl. 138.

FLETCHER, T.B. 1929. A list of generic names used for the Microlepidoptera. Mem.

Dep. Agric. India (Ent.) 11: 1-244.

- 1940. New generic names for Microlepidoptera. Entomologist's Rec. Jour. Var. 52: 17-19.

FoRBES, W.T.M. 1930. Insects of Porto Rico and the Virgin Islands. Scient. Surv. P. Rico 12: 1-171.

Grote, A.R. 1878. New species of Acopa and Heliothis, and note on Hamadryas.

Can. Ent. 10: 67-69.

HAMPSON, G.F. [1893]. Fauna of British India. Moths 1. London, 527p.

HePPNER, J.B.. 1984. Atlas of Neotropical Lepidoptera Checklist: Part 1. The Hague, W. Junk, 112p. 
1987. Corrigenda \& addenda. Neotrop. Lepid. News 1: 3-7.

Heppner, J.B. \& W.D. DuCKWorth. 1981. Classification of the Superfamily Sesioidea (Lepidoptera: Ditrysia). Smith. contr. zool. 314: 1-144.

Hodges, R.W. 1978. Gelechioidea. In: R.B. DoMINICK (Eds). The moths of North

America north of Mexico. Fasc. 6.1. London, Classey \& The Wedge Entomological Research Foundation, 166p.

1983. Oecophoridae, p.11-14. In: R.W. HodGES (Eds). Check list of the

Lepidoptera of America north of Mexico. London, E.W. Classey \& Wedge Entomological Research Foundation.

1997. Anew Agonoxeninae moth damaging Araucaria araucana needles in Western Argentina and notes on the Neotropical agonoxenine fauna (Lepidoptera: Gelechioidea: Elachistidae). Proc. entomol. Soc. Wash. 99: 267-278. HÜBNER, J. 1796-[1836]. Sammlung europäischer Schmetterlinge. 8. Tineae. Augsburg, 78p.

$431 \mathrm{p}$.

KÖHLER, P. 1941. Aegeriidae argentinas del Instituto Miguel Lillo (Lepidoptera,

Heterocera). Misc. Inst. Miguel Lillo, Tucuman, 4: 1-12.

MEYRICK, E. 1909. Descriptions of Micro-Lepidoptera from Bolivia and Peru.

Trans. ent. Soc. Lond. 1909: 13-43.

\section{Lond. 1910: 430-474.}

1913. Heliodinidae. Lepid. cat. 13: 9-22.

. 1914. H. Sauters Formosa Ausbeute. Supplta ent. 3: 45-62.

1915. Descriptions of South American Micro-Lepidoptera. Trans. ent.

Soc. Lond. 1915: 201-256.

. 1915b. Cosmopterygidae [sic!]. Exot. Microlepid. 1: 308-334.

61-66.

1917. Cosmopterygidae [sic!], Heliodinidae. Exot. Microlepid. 2: 30-53,

1921. Sesiadae [sic!]. Exot. Microlepid. 2: 441-444.

588 .

1922a. Cosmopterygidae [sic!], Heliodinidae. Exot. Microlepid. 2: 566-

1922b. Descriptions of South American Micro-Lepidoptera. Trans. ent.

Soc. Lond. 1922: 65-116.

1925. Gelechiadae. Genera insect. 184: 1-224.

1927. Heliodinidae. Exot. Microlepid. 3: 377-380.

1928. Cosmopterygidae [sic!]. Exot. Microlepid. 3: 384-396.

1930a. Ergebnisse einer zoologischen Sammelreise nach Brasilien, ins-

besondere in das Amazonasgebiet, ausgeführt von Dr. Zerny. Annln. naturh.

Mus. Wien 44: 223-268.

1930b. Blastobasidae, Heliodinidae. Exot. Microlepid 3: 579, 585-587.

1931. Cosmopterygidae [sic!] Oecophoridae, Heliodinidae. Exot. Micro-

lepid. 4: 51-56, 116-126, 174-176.

283.

1933. Gelechiadae. Exot. Microlepid. 4: 353-360. 

89-90.

NAUMANN, C.M. 1971. Untersuchungen zur systematik und phylogenese der Holarktischen Sesiiden (Insecta, Lepidoptera). Bonn. zool. Monograph. 1: 1-208.

NyE, I.W.B. \& D.S. FLETCHER. 1991. Generic names of the moths of the World. Microlepidoptera. London, Natural History Museum, Vol. 6, 368p.

TAVARES, J.S. 1917. As cecídias do Brazil que se criam nas plantas da família das Melastomataceae. Broteria, Ser. Zool. 15: 18-40.

WALKER, F. 1856. List of the specimens of Lepidopterous insects in the collection of the British Museum 8, p.1-271.

- 1864. List of the specimens of Lepidopterous insects in the collection of the British Museum 30, p.836-1096.

- [1865]. List of the specimens of Lepidopterous insects in the collection of the British Museum 31, p.1-321.

WALSINGHAM, L. 1889. Monograph of the genera connecting Tinaegeria, Walk., with Eretmocera. Z. Trans. ent. Soc. Lond. 1889: 1-40.

-1892. On the micro-lepidoptera of the West Indies. Proc. zool. Soc. Lond. 1891: 492-549.

- 1897. Revision of the West-Indian Micro-Lepidoptera, with descriptions of new species. Proc. zool. Soc. Lond. 1897: 54-183.

- 1909-1915. Tineina, Pterophorina, Orneodina and Pyralidina and Hepialina (part). Biologia cent.-am. (Zool.) Lepid.-Heterocera 4: 1-483.

ZELLER, P.C. 1877. Exotische Microlepidoptera. Horae Soc. ent. rossicae 13: 3-493.

Zukowsky, B. 1936-1937. Aegeriidae, p. 1215-1262. In: A. SEITZ (Ed.). Die Gross-Schmetterlinge der Erde. Band 6. Stuttgart, Alfred Kernen.

Recebido em 20.VIII.1998; aceito em 29.XI.1999. 